\title{
BOUNDARY LEARNING IN A GENDER RESPONSIVE CURRICULUM TRANSFORMATION IN ZIMBABWE: AN ACTIVITY THEORY APPROACH
}

\author{
APRENDIZADO DE FRONTEIRAS EM UMA TRANSFORMAÇÃO \\ CURRICULAR SENSÍVEL AO GÊNERO NO ZIMBÁBUE: UMA \\ ABORDAGEM BASEADA NA TEORIA DA ATIVIDADE
}

\section{APRENDIZAJE FRONTERIZO EN UNA TRANSFORMACIÓN DE CURRÍCULO SENSIBLE AL GÉNERO EN ZIMBABUE: UN ENFOQUE DESDE LA TEORÍA DE LA ACTIVIDAD}

\author{
Charles Chikunda ${ }^{1}$ \\ Rhodes University, Professor in the Department of Education (Hoedspruit/Limpopo - South \\ Africa) \\ Plaxcedes Chikunda ${ }^{2}$ \\ Great Zimbabwe University (Gweru - Zimbabwe), Professor of Sociology of Education

\section{Rafael Fonseca de Castro ${ }^{3}$} \\ Federal University of Rondônia, Professor in the Education Sciences Department
}

\begin{abstract}
This paper aims to share insights of a boundary learning process in a curriculum transformation in Zimbabwe. It is based on the dialectical lenses of Cultural-Historical Activity Theory (CHAT). The boundary learning epistemic actions were designed/interpreted using CHAT tools of double stimulation, activity system and expansive learning. The main findings are two types of boundary learning: individual and institutional. Individual focused on questioning and confronting tensions in current individual curriculum practice. Institutional refers to collaborative relationships between hierarchical levels of the teacher education system in Zimbabwe. We point to the need for theoretical and conceptual rigor in studies on curriculum transformation,

\footnotetext{
${ }^{1} \mathrm{PhD}$ in Education at Rhodes University (South Africa); Master's Degree in Education at University of Zimbabwe (Zimbabwe).

${ }^{2}$ Master's in Education at Midlands State University (Zimbabwe); Bachelor's Degree in Education at University of Zimbabwe (Zimbabwe).

${ }^{3} \mathrm{PhD}$ and Master's Degree in Education at Federal University of Pelotas (UFPel).
} 
arguing for careful attention to empirical evidence of transformation/transgressing current practices in any expansive learning process. There is also need to think through the policy-practice gap, especially in curriculum development.

Keywords: CHAT. Boundary learning. Gender responsive. Curriculum transformation.

Resumo: Neste artigo tem-se como objetivo compartilhar informações sobre o processo de aprendizagem de fronteiras, em uma iniciativa de transformação curricular no Zimbábue. Baseia-se nas lentes dialéticas da Teoria Histórico-Cultural da Atividade (CHAT). As ações epistêmicas de aprendizagem de fronteiras foram projetadas/interpretadas usando pressupostos da CHAT de dupla estimulação, sistema de atividade e aprendizado expansivo. Os principais achados são dois tipos de aprendizagem de fronteiras: individual e institucional. A individual está concentrada em questionar e enfrentar as tensões em práticas atuais em termos de currículo individual. A institucional refere-se a relações colaborativas entre os níveis hierárquicos do sistema de ensino de professores no Zimbábue. Aponta-se para a necessidade de maior rigor teórico e conceitual em estudos de transformação curricular, argumentando a atenção cuidadosa em evidências empíricas de transformação/transgressão de práticas atuais em qualquer processo de aprendizado expansivo. Também é necessário pensar em lacunas nas políticas públicas, especialmente no desenvolvimento curricular.

Palavras-chave: CHAT. Aprendizado de fronteiras. Sensível ao gênero. Transformação curricular.

Resumen: Este articulo tiene como objetivo compartir las ideas de un proceso de aprendizaje fronterizo en una transformación curricular en Zimbabue. Se basa en las lentes dialécticas de la Teoría Histórico-Cultural de La Actividad (CHAT). Las acciones epistémicas de aprendizaje fronterizo fueron diseñadas/interpretadas utilizando herramientas de CHAT, doble estimulación, sistema de actividad y aprendizaje expansivo. Los principales hallazgos son dos tipos de aprendizaje fronterizo: individual e institucional. La individual se centró en cuestionar y confrontar las tensiones en la práctica curricular individual actual. La institucional se refiere a las relaciones de colaboración entre los niveles jerárquicos del sistema de educación de maestros en Zimbabue. Señalamos la necesidad de rigor teórico y conceptual en los estudios sobre transformación, argumentando que se debe prestar atención a la evidencia empírica de transformación/transgresión de las prácticas actuales en cualquier proceso expansivo de aprendizaje. También es necesario pensar en la brecha política-práctica, especialmente en el desarrollo curricular.

Palabras clave: CHAT. Aprendizaje fronterizo. Sensible al género. Transformación curricular. 


\section{INTRODUCTION}

In Zimbabwe, like in most other African countries, the (physical) Sciences, Technology, Engineering, and Mathematics (STEM) are still male dominated. This is despite numerous efforts over the years directed towards gender equality in these disciplines. The main thrust of this paper is to share insights from the boundary learning process that was conducted in a small scale expansive learning process as a way of contributing towards gender responsive curriculum transformation in a teacher education institution in Zimbabwe. The article is structured in three sections. The first section gives a brief background to the gender issues in education focusing on STEM. The section also looks at the teacher education setup in Zimbabwe, highlighting the complexity with regards to curriculum transformation of any kind. The second section dwells on the methodological and theoretical lenses that guided the work reported in this article. Key concepts framing this article are briefly explained in this section. The third and final section deliberates on two processes; firstly consolidating tensions with regards to gender responsive curriculum practices in STEM in teacher education (TE). Secondly, the section articulates the actual boundary learning process highlighting the mediation process as well as reflections on boundary learning.

\section{BACKGROUND AND CONTEXT}

Economic and social development in any country relies heavily on a sound technology base, which can be achieved by putting emphasis on STEM subjects at all levels of the education system. Ensuring good health, fighting diseases, protecting the environment, farming and developing agriculture, developing new industries and technologies, and even building resilience to climate change are all activities that require knowledge and skills offered by these disciplines. It therefore, follows that there is need to harness the intellectual and scientific capacity of both men and women for a sustainable social and economic development of any country. Ironically, STEM constitutes the areas within the educational system where gender disparity, in several of the poorest countries of the world, is greatest (SINNES, 2006; CLEGGY, 2007; FORUM FOR AFRICAN WOMEN EDUCATIONALISTS, 2008; ZIMBABWE, 2010). Research has shown a persistently visible gender disparity in these disciplines which is glaring from secondary school level and beyond, characterized by low female enrolment, poor performance and low retention. For example, Board 1 below shows the percentages of men and women in the faculties of science in selected SADC countries. 
Board 1 - Percentage of men and women in Faculties of Science

\begin{tabular}{|c|c|c|c|c|c|c|c|c|c|c|c|c|c|c|c|c|c|c|c|}
\hline \multicolumn{2}{|c|}{$\begin{array}{l}\frac{\pi}{0} \\
\text { on } \\
\text { 安 }\end{array}$} & \multicolumn{2}{|c|}{ 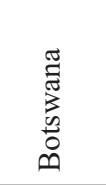 } & \multicolumn{2}{|c|}{ 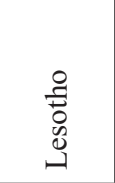 } & \multicolumn{2}{|c|}{$\frac{\sqrt{\frac{\pi}{\pi}}}{\sum_{\Sigma}^{\pi}}$} & \multicolumn{2}{|c|}{ 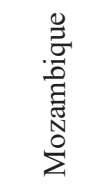 } & \multicolumn{2}{|c|}{ 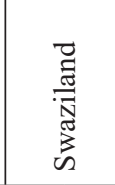 } & \multicolumn{2}{|c|}{ 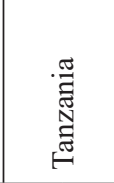 } & \multicolumn{2}{|c|}{$\begin{array}{l}\frac{\pi}{0} \\
\frac{\tilde{J}}{\tilde{N}} \\
\text { N }\end{array}$} & \multicolumn{2}{|c|}{ 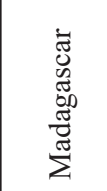 } & \multicolumn{2}{|c|}{$\begin{array}{l}0 \\
\text { है } \\
\text { त्ञ } \\
\text { है }\end{array}$} \\
\hline $\mathrm{F}$ & M & $\mathrm{F}$ & $\mathrm{M}$ & $\mathrm{F}$ & $\mathrm{M}$ & $\mathrm{F}$ & $\mathrm{M}$ & $\mathrm{F}$ & $\mathrm{M}$ & $\mathrm{F}$ & $\mathrm{M}$ & $\mathrm{F}$ & $\mathrm{M}$ & $\mathrm{F}$ & $\mathrm{M}$ & $\mathrm{F}$ & $\mathrm{M}$ & $\mathrm{F}$ & $\mathrm{M}$ \\
\hline 40 & 60 & 28 & 72 & 26 & 74 & 37 & 63 & 23 & 77 & 28 & 72 & 30 & 70 & 35 & 65 & 33 & 67 & 24 & 76 \\
\hline
\end{tabular}

Source: Morna and Nyakujarah (2011, p. 96).

Researchers who advocate for gender equality in sciences (KALU, 2005; CLEGGY, 2007; FORUM FOR AFRICAN WOMEN EDUCATIONALISTS, 2008; CHIKUNDA, 2010) argue that one major hindrance to participation of girls in STEM is the lack of gender responsiveness in the pedagogy applied in schools. This is further confirmed by the fact that, although it is now common knowledge that gender imbalances in STEM exist, teachers are often unaware of or non-accepting this situation and would not naturally feel the need to address it (FORUM FOR AFRICAN WOMEN EDUCATIONALISTS, 2008). Such research evidence seems to suggest that STEM teachers are not receiving from their teacher education the necessary skills, knowledge, values and attitude to engage with social issues such as gender in their curriculum practice. It is such glaring evidence of gender inequality in education that arouses critics to question the commitment of teacher education, as a human development and training sector, to the global efforts towards gender equality in education as a means towards social justice.

This study therefore focused on teacher education STEM curriculum. Teacher education setup in the country is best described by three institutions taken heuristically as activity systems (see below); the teachers' college as the central activity system, interacting with the Ministry of Higher Education and the Department of Teacher Education (DTE) activity systems. The DTE is under the faculty of education at the University of Zimbabwe, an institution that is mandated to monitor teacher education in the country. It approves curriculum for polytechnics and teachers' colleges through its multiple roles concerning education, research, supervision, and extension courses throughout the country. DTE works in unison with the Ministry of Higher Education (also known as Head Office (HO), which administers teachers' colleges in the country. The teacher education wing under this ministry is responsible for curriculum development; implementing policy decisions from cabinet into curriculum innovations 
and linking regional and international directives with teacher education curriculum. Another dimension added to this complexity is that of the gender focal person, an individual appointed by the Ministry of Gender and Women Affairs to every ministry to spearhead gender mainstreaming in that specific ministry.

In this article, we share insights from the boundary learning process that was conducted in a bid to support curriculum transformation towards gender responsivity in STEM in one of the pre-service teacher education college in Zimbabwe. The college was purposively sampled as it is the biggest college that produces secondary school teachers for a broad range of STEM. Boundary learning is conceptualized in the realm of expansive learning. This article does not go deeply into surfacing tensions that may constrain implementation of gender-responsive curriculum practices in STEM teacher education in Zimbabwe. For such reviews, see Chikunda $(2010,2014$, 2015). Also, this article does not cover the whole broad spectrum uses of the Cultural-Historical Activity Theory (CHAT) in educational research, this has been widely studied (ROTH; LEE, 2007; WARMINGTON et al., 2005; SELAU; CASTRO, 2015, and more). As indicated above, the main thrust of the paper is to share insights from the boundary learning process that was conducted in a small scale expansive learning process, towards gender responsive curriculum transformation.

\section{METHODOLOGY AND THEORETICAL FOCUS}

Methodologically, the research was guided by the Cultural-Historical Activity Theory, or simply Activity Theory (AT), which is an interdisciplinary approach to human sciences research that originates in the cultural-historical psychology school initiated by Vygotsky, Leontiev and Luria (ENGESTRÖM; MIETTINEN, 1999). The paper draws on AT tools such as expansive learning, activity system analysis, as well as applying second and third generation CHAT lenses as described below. Vygotsky's methodology of double stimulation was used in change laboratory (CL) workshops. In the following section, we briefly describe how each of these tools was used in this work.

The concept boundary learning subsumes that there are conceptual and physical boundaries to be crossed in a transformative learning process. Boundaries in everyday actions occur when a person encounters a problem or dilemma as an expression of those boundaries (KEROSUO; ENGESTRÖM, 2003). Boundary crossing, which was the main focus of all CL workshops described in this paper, was meant to navigate through different languages, registers and cultural issues, as well as local worlds of meaning (SHOTTER; KATZ, 1999. Initial scoping for this work, Chikunda (2013) gave 
a sense that two types of boundaries occur with regard to gender and STEM teacher education. These are individual and institutional boundaries after Kerosuo and Engeström (2003). The individual boundary describes inherent practice based sense and meaning making inherent in the individual teacher educator in relation to the curriculum transformation at hand. Institutional boundary in this case refers to collaborative relationships between hierarchical levels of the teacher education system.

The activity system analysis (AS) is articulated in second generation CHAT, as visualized in Figure 1, and it comprises a group of people pursuing a goal in a purposeful way (PEAL; WILSON, 2001). Blacker, Crump and Macdonald (2000, p. 281) added that the "activity system comprises of an interrelated bricolage of material, mental, social and cultural resources for thought and action". Figure 1 below shows elements of an activity system and their relationship. As Engeström (2016, p. 3) puts it, AT is a theory of object-driven activity. "Objects are concerns, they are generators and foci of attention, motivation, effort and meaning." Second generation CHAT was the main tool used to conceptualise individual boundary learning at teacher education (TE) activity system as described in the following section.

Figure 1 - Diagnostic questions for individual boundary learning in the teacher education activity system using second generation CHA

Tools: What cultural and historical artefacts are in place and being used to support gender responsive curriculum practices in STEM teacher education? Do subjects (teacher educators) have sufficient skills to use the available tools effectively? What knowledge and skills are needed?

Rules: What cultural historical norms \& rules govern the incorporation of gender responsive practices in STEM teacher education curriculum?
Subjects: What is the level of gender responsiveness of STEM teacher educators?

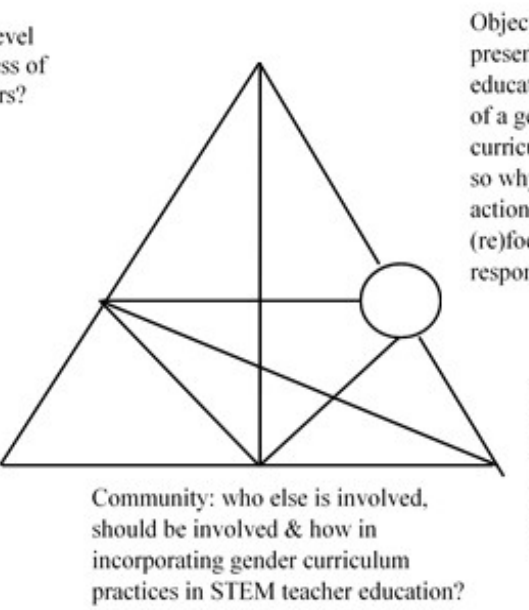

Object: How well suited are the present actions in STEM teacher ucation curriculum to the goals a gender responsive lum? Is there is a misfit? If ions/activities can be (re)focused towards gender responsivity?

\section{Division of labour: Who} should do what and why in incorporating gender responsive practices in STEM teacher education curriculum?

Source: adapted from Engeström (2001, 2016) and Chikunda (2015). 
It is, in the conceptualization of CHAT's third generation (Diagram 1), that the idea of boundary crossing or institutional boundary learning gains significance. In this case participants/actors belonging to the different activity systems (TE; DTE \& HO) have a shared object, that of gender curriculum transformation. With the same idea, Roth and Lee (2007) emphasized that in the third generation of CHAT, boundaries, in the form of contradictions between activity systems, are seen as vital forces for change and development. A boundary can be seen as a socio-cultural difference leading to discontinuity in action or interaction (AKKERMAN; BAKKER, 2011). At the same time, boundaries simultaneously suggest a sameness and continuity in the sense that within discontinuity two or more sites are relevant to one another in a particular way (AKKERMAN; BAKKER, 2011). Akkerman and van Eijck (2013, p. 4) explained that boundaries between social practices are "[...] not lines of distinction but ambiguous, in that they represent a neither/nor, as well as a both/and situation... when people cross boundaries their position is one of belonging to multiple worlds, but also one of being a marginal stranger to each of these worlds."

Diagram 1 - Conceptualizing institutional boundary learning between activity systems

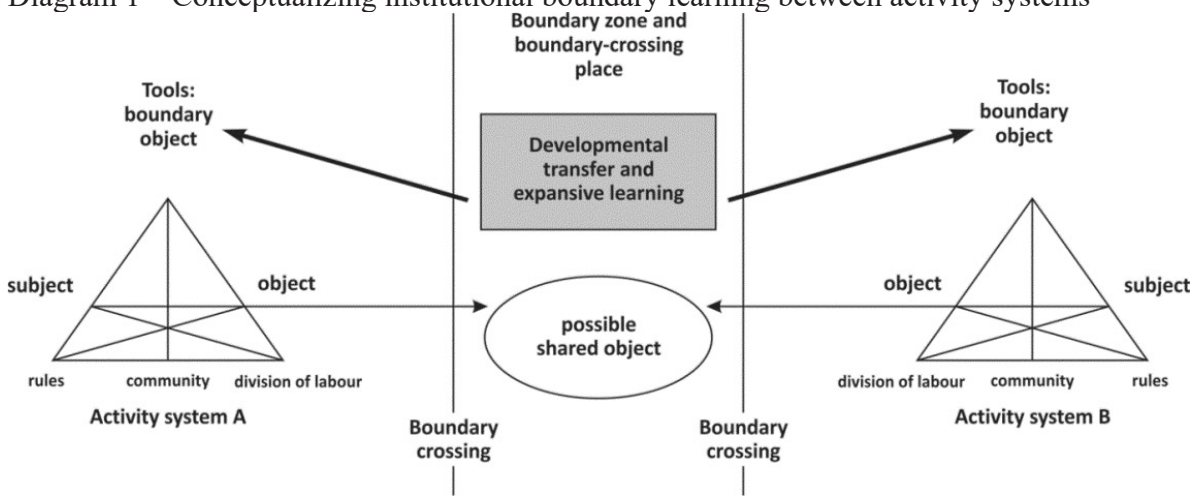

Source: Engeström (2004, p. 23).

Expansive learning (EL) is a method of intervention, developed in Finland by Engeström and his colleagues since the 1980s, based on Vygotsky's method of double simulation (ENGESTRÖM, 2007; SANNINO, 2008). The theory of expansive learning focuses on learning processes in which the very subject of learning is transformed from isolated individuals to collectives and networks (ENGESTRÖM, 2016). As shown in Diagram 2, EL is a spiral characterised by specific epistemic or learning actions. 
This paper pays particular attention to the first ${ }^{4}$ three learning actions, questioning, analysis and modelling.

Diagram 2 - EL model showing learning stages in the transformation process

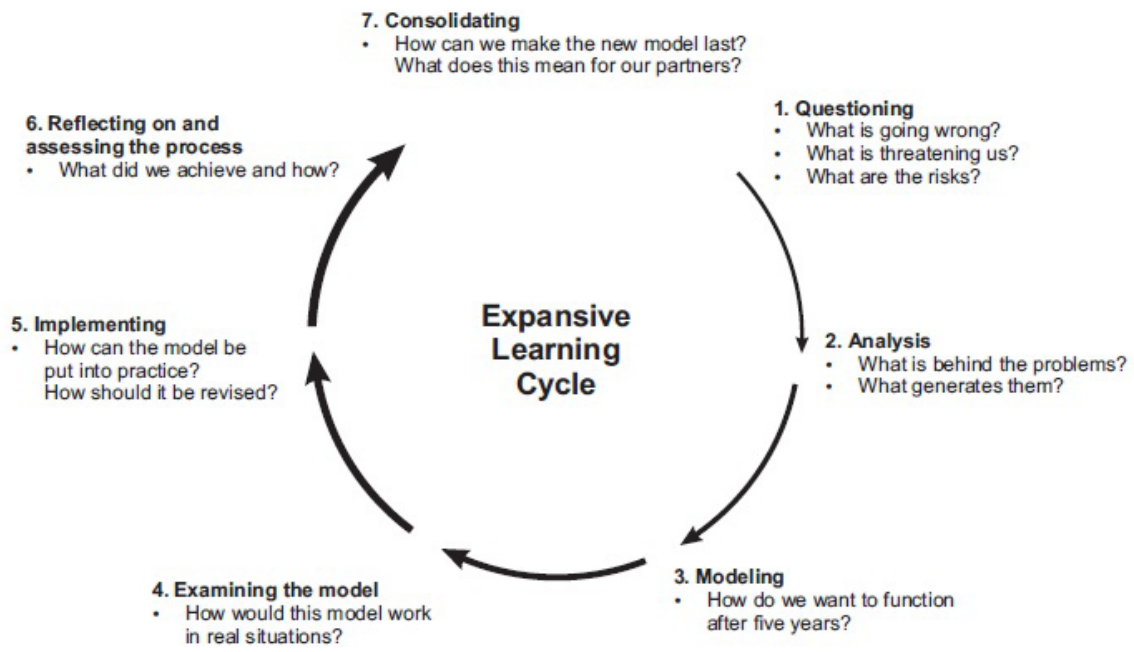

Center for Research on Activity, Development and Learning Cradle 2015

Source: adapted from Engeström (2016).

Change Laboratory Workshop (CL) was the main methodological tool that was used for boundary learning in this study. CL is a participatory approach which implements the cycles of EL shown in Diagram 2. The objective is to engage practitioners in reflective cycles of confronting, deconstruction, reconstruction, trial and readjustment, revealing the needs and possibilities for development in work. Sannino (2008) added that the central idea behind CL is that educational and work practices can develop through collective, cognitive, and material reconceptualization of the object of activity. In this case, CL workshops were designed to support reflexive systemic analysis by confronting practitioners "everyday" understanding with "scientific" understanding of system relationships, dynamics and the structural contradictions that might point towards new, expanded forms of practice.

\footnotetext{
${ }^{4}$ There is a thin line dividing learning actions 1-3. For instance in the process of modeling potential solutions more questions arise and analysis continues. Nonetheless, see also Chikunda $(2013,2014)$ for detailed account on tensions around gender responsive curriculum practices in science teacher education in Zimbabwe.
} 
A total of three change laboratories with several sessions each were held. The first change laboratory was held with the teacher education (TE) activity system, the central activity system. It took a total of 12 hours. It stretched over three weeks with two hours per day and two days a week. The second change laboratory was held with Head office (HO) comprising of higher education ministry officials including the gender focal person in the Ministry and the Department of Teacher Education representatives. It took half a day (9 a.m. to 1 p.m.). The last change laboratory took three half days spanning over two weeks. It brought together all the activity systems of the case study: Department of Teacher Education officials, Ministry officials and teacher educators.

The Double stimulation concept came from Vygotsky's work that describes the emergence of transformative action as a process involving two apparatuses which are relatively independent of each other (SANNINO, 2008). The first stimulus is the object, the problem space to be worked on that manifests as disturbances that stakeholders experience every day in relation to their environment. In this case, this is gender equity in STEM. A second stimulus is usually provided by the researcher or designed collaboratively in the learning process to assist participants to make sense of the information available. The second stimulus, according to Virkkunen and Newnham (2013), is meant to be a psychological tool to assist participants in two ways. First, to grasp the relationship between observations and building a systemic understanding of the context. Secondly, finding the inner contradictions in the system that produce the challenges that people encounter in their daily lives. In this regard, policy pronouncements and research data on gender and STEM were used as second stimuli to provide that external auxiliary means for mastering the object (problem space) in a more holistic framing.

\section{BOUNDARY CROSSING FROM QUESTIONING TO MODELLING}

As hinted above, three Activity Systems ${ }^{5}$ (AS) were involved in curriculum transformation boundary learning, namely TE, DTE and HO. The first CL focused on individual boundary and this was held with the teacher education AS. The purpose of the CL was to assist teacher educators to confront their context with regards to gender responsive in STEM teacher education curriculum. The second CL, focused on institutional boundary ${ }^{6}$ learning, bringing together all three AS.

\footnotetext{
${ }^{5}$ See Chikunda (2013) for comprehensive description of these activity systems.

${ }^{6}$ Preliminary work involving focus group discussions and in-depth interviews was done with each AS before combined CL sessions. Because of space restriction, the data cannot be shared in this article.
} 


\subsection{BOUNDARY LEARNING WITH THE TEACHER EDUCATION ACTIVITY SYSTEM (QUESTIONING AND ANALYSIS)}

Reconceptualization of the object was done through questioning current practice. To stimulate this, the posed lead question was: Are we doing enough in teacher education to equip future teachers with the required knowledge, skills, values and attitudes to handle gender issues in STEM learning? The problem solving questions acted as the second stimuli in these workshops. This is in accordance with Vygotsky (1978, p. 74-75) who argued that:

By using this approach, we do not limit ourselves to the usual
method of offering the subjects simple stimuli to which we ex-
pect a direct response. Rather, we simultaneously offer a second
series of stimuli that have a special function. In this way, we are
able to study the process of accomplishing a task by the aid of
specific auxiliary means; thus we are also able to discover the in-
ner structure and development of higher psychological processes.

Discussion around the question led to claims like "we speak about it, we sensitize them (trainee teachers)... we always try to make a reference to that, [...] we always point it out that they (trainee teachers) should try as much as possible to motivate our girl child out there to join maths/science." It was evident that the question had led participants to respond to the level of visible individual actions and events. There was more or less consensus nonetheless among teacher educators that they were doing the best they could to equip future STEM teachers with the required knowledge, skills, values and attitudes to handle gender issues in their own pedagogic practice. To deepen the discussion to invisible dynamics of the activity system we used mirroring ${ }^{7}$ using the Zimbabwe National Gender Policy (Board 2) as another auxiliary stimulating object.

Board 2 - Mirror data from the NGP

Teacher Training Institutions are required to:

1. Incorporate gender issues in all curricula at all levels of education;

2. Eliminate all forms of discrimination against boys and girls in education and skills training which includes science and technology;

3. Promote and encourage girls to take on science, mathematics and technology at all levels of education;

4. Introduce gender awareness programmes to pre- and post-training teacher courses.

Source: the authors.

${ }^{7}$ What is mirroring in EL? 
Participants worked in small groups for a focus group discussion, to discuss whether and/or how as teacher educators they are responding to such policy pronouncements. Midway, participants raised the need to have a lecturer in charge in every group as some of the policy pronouncements require input from management. Participants were reminded that input from Focus Group Discussion was to feed into the problem solving question: Are we doing enough in teacher education to equip future teachers with the required knowledge, skills, values and attitudes to handle gender issues in STEM learning? To cover more ground in the short time provided, we agreed that each Focus Group Discussion concentrate on two of the policy statements in Board 2. We also agreed that each Focus Group Discussion should discuss policy statement 1, because it was critical to curriculum practice. Flip chart summaries came as shown in Board 3. The column emerging tensions shows reveal contradictions within the TE activity system. With reference to the diagnostic questions in Figure 1, it emerged that although teacher educators could see gender disparities in terms of enrolment and retention, they did not possess the required tools and analytical lenses to undertake a deeper analysis of the causes of such gender disparities and the implications for girls studying STEM, nor did they have capacity for working against these in their practice.

Board 3 - Summary of group reports and emerging contradictions

\begin{tabular}{|c|c|c|}
\hline $\begin{array}{l}\text { Policy state- } \\
\text { ment }\end{array}$ & Report & Emerging tensions \\
\hline $\begin{array}{l}\text { Incorpora- } \\
\text { te gender } \\
\text { issues in all } \\
\text { curricula at } \\
\text { all levels of } \\
\text { education. }\end{array}$ & $\begin{array}{l}\text { - encourage trainee teachers to be } \\
\text { sensitive; } \\
\text { - recommend that they encourage } \\
\text { girls not to be shy but to be active; } \\
\text { - use different examples that appeal } \\
\text { to both boys and girls. }\end{array}$ & $\begin{array}{l}\text { Misunderstood the concept of "in- } \\
\text { corporating" into the curriculum } \\
\text { No evidence of engaging with: } \\
\text { - sexist bias in resources, content } \\
\text { and language; } \\
\text { - content, teaching methods and }\end{array}$ \\
\hline $\begin{array}{l}\text { Eliminate all } \\
\text { forms of dis- } \\
\text { crimination } \\
\text { against boys } \\
\text { and girls in } \\
\text { education } \\
\text { and skills } \\
\text { training whi- } \\
\text { ch includes } \\
\text { science and } \\
\text { technology. }\end{array}$ & $\begin{array}{l}\text { - affirmative action at enrolment } \\
\text { level; } \\
\text { - treat girls equal/the same in class; } \\
\text { - introduce some incentives like } \\
\text { bursaries to keep girls in STEM; } \\
\text { - we need to encourage future } \\
\text { teachers to consider culture and } \\
\text { traditional practices; } \\
\text { - issues of gender roles should be } \\
\text { considered as well. }\end{array}$ & $\begin{array}{l}\text { classroom dynamics that encompass } \\
\text { girls' b ackground and learning } \\
\text { styles; } \\
\text { - parents informing them about the } \\
\text { importance of science to girls; } \\
\text {-informing learners about women } \\
\text { role models; } \\
\text { - ontology and epistemology of } \\
\text { STEM not considered; } \\
\text { - de-emphasizing sex-role stereo- } \\
\text { typing that hinder girls' progress in } \\
\text { science. }\end{array}$ \\
\hline
\end{tabular}




\begin{tabular}{|c|c|c|}
\hline $\begin{array}{l}\text { Introduce } \\
\text { gender } \\
\text { awareness } \\
\text { programmes } \\
\text { to pre- and } \\
\text { post-training } \\
\text { teacher } \\
\text { courses. }\end{array}$ & $\begin{array}{l}\text { - seeing the national gender policy } \\
\text { for the first time; } \\
\text { - not sure how to translate this into } \\
\text { the curriculum practice; } \\
\text { - more training needed for teacher } \\
\text { educators. }\end{array}$ & $\begin{array}{l}\text { - no written gender policy/program; } \\
\text { - no institutionalized program to- } \\
\text { wards gender responsive curriculum } \\
\text { practices. }\end{array}$ \\
\hline $\begin{array}{l}\text { Promote and } \\
\text { encourage } \\
\text { girls to take } \\
\text { on science, } \\
\text { mathema- } \\
\text { tics and } \\
\text { technology at } \\
\text { all levels of } \\
\text { education. }\end{array}$ & $\begin{array}{l}\text { - affirmative action at enrolment } \\
\text { level; } \\
\text { - teachers should encourage girls to } \\
\text { participate in sciences as well; } \\
\text { - teachers should convey the messa- } \\
\text { ges to girls that we are all the same } \\
\text { and there is nothing like subjects for } \\
\text { boys and some for girls. }\end{array}$ & $\begin{array}{l}\text { Absence of pedagogical approaches } \\
\text { and other curriculum initiatives in } \\
\text { this regard to inculcate skills, kno- } \\
\text { wledge and values in future STEM } \\
\text { teachers. } \\
\text { No reference made to the relevancy } \\
\text { and quality of STEM. }\end{array}$ \\
\hline
\end{tabular}

Source: the authors.

Also emerging from the CL workshops, there were also contradictions amongst participants, especially from TE activity system, as some individuals expressed views of not wanting to change or not seeing anything wrong in the way they were doing things, noting that they want to teach "science" and not sociology.

But guys remember we are here to teach science, mathematics, etc. and not sociology.

How does this gender thing come in when I am teaching the periodic table for example?

Science is about facts and principles, proven things and I am not sure how this gender issue comes in. (verbal information).

This depicted dissonance or critical conflicts, situations in which people face inner doubts that paralyze them in front of contradictions between motives unsolvable by the participant alone; it is "the response to a situation of impossibility or unintelligibility." (VASILYUK, 1988). Nonetheless, as aspects of contradictions were articulated more and more in several CL sessions, there was a visible shift from being wary to a resolve to doing something about the situation as discussed in the following sections.

With such experiences, there was the need to introduce another stimulating tool that made teacher educators further question their practice. This came in the form of a summary of research findings from literature that provides some of the reasons 
for girls' avoidance of STEM. The idea was to add on to the instrumentality and mediation tools that teacher educators could engage with in a transformation move towards a curriculum that is potentially a gender conversion agent. Since there, is a lot of information in this area. A handout ${ }^{8}$ was prepared and was given to participants to take home and to reflect on before the following session. In a way this was stimulus for teacher educators to remain focused on curriculum transformation.

The following session started with a review of the problem solving question. ${ }^{9}$ In view of the contents of the research findings summarized in the handout, some participants suggested that we break the question down into manageable units to better reflect on how teacher education is helping teachers to be gender responsive in their practice as pointed to by the research findings. We agreed to have sub questions: what is happening now; possible reasons for what is not happening; and what is lacking/what is needed for the not happening to happen (absenting the absence). From CHAT interventionist research point of view, such suggestions could be interpreted as: what is happening/obtaining now; life state of practice; possible reasons for what is not happening, contradictions, need state, double bind; and what is lacking/what is needed for the not happening to happen, pointing towards modelling solutions.

We further interpreted this as a leading to a deepening of analysis of the own practice and eventually to sharper and more articulated questioning. Furthermore, as advanced by Warmington et al. (2005) such mediational settings support participants and researchers to make the current activity visible for interrogation, reshaping and experimentation. It was also evident that the mirrored data supported reflective systemic analysis, enabling participants to confront their everyday understanding with the Vygotskian scientific understanding of system relationships, dynamics and the structural contradictions that might point towards new, expanded forms of practice. In other words, this was really an example of "agentive talk" - expressing a willingness to address the contradictions (MUKUTE, 2010, p. 147).

\footnotetext{
${ }^{8}$ Handout summary - prepare future teachers with knowledge, skills and positive attitude to: analyze sexist bias/gender stereotypes in resources, content and language; examine content, teaching methods and classroom dynamics that encompass girls' and boys' interest, experiences and learning styles; deemphasizing sex-role stereotyping that hinder girls' progress in science; draw the attention of boys and girls to the presence and contributions of women in science and mathematics; to be on the watch out for boys/ girls who want to dominate classroom proceedings to the detriment of others; ensure that future teachers are able to deal with counter cultural practices that may impact negatively on girls'/boys' pursuance of sciences; various ways to help empower girls and raise their self-esteem in sciences; add relevance and quality to science by drawing attention to socio-ecological issues; be sensitive gender connotations in learning contexts; Issues of relevance and quality of education; critical thinking in STEM; add relevance and quality to STEM by drawing attention to socio-ecological issues.

${ }^{9}$ Are we doing enough in teacher education to equip future teachers with the required knowledge, skills, values and attitudes to handle gender issues in STEM learning?
} 
Participants discussed different research findings extracted from the handout and each group focused on a different theme but were all guided by the problem solving question above. Board 4 presents a summary of the session reports:

Board 4 - Summary of reflections on gender issues in the curriculum

\begin{tabular}{|c|c|c|}
\hline What is happening now & Possible reasons & What is needed \\
\hline $\begin{array}{l}\text { - visible gender disparities in } \\
\text { STEM; } \\
\text { - talk about gender disparities } \\
\text { in general - no institutionalized } \\
\text { pedagogic practice as suggested } \\
\text { in literature and as required by the } \\
\text { National Gender Policy; } \\
\text { - not enough to equip future tea- } \\
\text { chers; } \\
\text { - previous gender responsive peda- } \\
\text { gogies staff developments genera- } \\
\text { lize and not in such detail and not } \\
\text { focused to STEM. }\end{array}$ & $\begin{array}{l}\text { - aware of gender disparity } \\
\text { in terms of enrolment figu- } \\
\text { res not aware of the causal } \\
\text { mechanisms; } \\
\text { - lack of tools to translate } \\
\text { policy into practice; } \\
\text { - not aware of other ways } \\
\text { of doing it (scientism } \\
\text { influence pedagogical } \\
\text { practices); } \\
\text { - patriarchal norms } \\
\text { influencing curriculum } \\
\text { practice. }\end{array}$ & $\begin{array}{l}\text { - not to conflate con- } \\
\text { cepts gender parity, } \\
\text { equity and equality; } \\
\text { - not to conflate process } \\
\text { in curriculum practice } \\
\text { of gender awareness, } \\
\text { sensitivity and response; } \\
\text { - an institutionalized } \\
\text { response to gender } \\
\text { issues in STEM; } \\
\text { - mediation tools for } \\
\text { gender curriculum } \\
\text { practices. }\end{array}$ \\
\hline $\begin{array}{l}\text { - STEM teacher educators not equi- } \\
\text { pping future teachers with skills, } \\
\text { knowledge and attitude to handle } \\
\text { the following: } \\
\text { • sexist bias that may be in resour- } \\
\text { ces, content and language; } \\
\text {-gender prejudice; } \\
\text { - content, teaching methods and } \\
\text { classroom dynamics that encom- } \\
\text { pass girls' background and learning } \\
\text { styles; } \\
\text { - keeping parents informed about } \\
\text { importance of science to girls; } \\
\text { - informing learners about women } \\
\text { role models; } \\
\text { - de-emphasizing sex-role stereo- } \\
\text { typing that hinder girls' progress in } \\
\text { science. }\end{array}$ & $\begin{array}{l}\text { - teacher educators not } \\
\text { aware of policies that can } \\
\text { support them to incorpo- } \\
\text { rate gender into STEM; } \\
\text { - not aware of other ways } \\
\text { of doing it "we teach the } \\
\text { way we were taught to do } \\
\text { in our professional devel- } \\
\text { opment"; } \\
\text { - view that STEM are not } \\
\text { social sciences but pure } \\
\text { sciences (scientism); } \\
\text { - rigid, well defined and } \\
\text { exam driven curriculum. }\end{array}$ & $\begin{array}{l}\text { - learn more concerning } \\
\text { ESD and curriculum } \\
\text { practices; } \\
\text { - to be assisted to } \\
\text { translate policy into cur- } \\
\text { riculum practice; } \\
\text { - mediation tools to } \\
\text { incorporate issues of } \\
\text { equity and socio-eco- } \\
\text { logical risk for quality } \\
\text { and relevancy of STEM. }\end{array}$ \\
\hline
\end{tabular}

Source: the authors.

Note: The belief that science is authoritarian, non-humanistic, objective, purely rational and empirical, universal, impersonal, socially sterile and unencumbered by human bias, dogma or cultural values (AIKENHEAD, 2002). 
The "what is needed" column pointed towards modelling solutions and the concerns raised became part of the mirror data for the following change laboratory session. There were also questions like: "who should translate policy into curriculum doable"? Is it the policy maker or the implementer? Every participant appeared to have this concern and the question was raised in the context of what are referred to as cross-cutting policies, like the National Gender. The general feeling was that such policies may require additional knowledge and skills that some ordinary professionals in certain fields may not possess, but all the same they are required to implement the policy in their pedagogical practice.

This concern pushed the unit of analysis into third generation of CHAT as it shifted from curriculum practice of teacher educators to the interaction between the teacher education activity system and various other institutions (activity systems) that share the common object of teacher education. In other words the situation required institutional boundary crossing learning. The concern also made it evident that teacher educators were becoming certain of their uncertainties in curriculum development. This was a 'cry' for help, for scaffolding, and for boundary objects to facilitate learning across the zone of proximal development (ENGESTRÖM, 2001), the distance between the present everyday actions of the individuals and the historically new form of the societal practice that can be collectively generated as a solution to the double bind potentially embedded in the everyday actions. As interventionist researchers, we took note of this concern as one of the issues to be mirrored in future change laboratories with relevant activity systems.

\subsection{BOUNDARY LEARNING WITH ALL THE ACTIVITY SYSTEMS INSTITUTIONAL BOUNDARY LEARNING}

The purpose of this Change Laboratory was to provide a space for all the activity systems to come together and reconceptualize the object (coming up with a gender responsive STEM teacher education curriculum). The idea was to build on what Engeström (2007) refers to as distributed agency or collective intentionality. The process was meant to facilitate boundary learning across activity systems.

The change laboratory took place over three and a half days. Representatives from the DTE, HO were present in the sessions. The head office team included the gender focal person and a UNESCO desk official. The TE AS was graced by the senior lecturers of the three STEM departments (Sciences, Mathematics and Technical subjects). These are key figure in any curriculum development initiative. 
Two problem solving artefacts were key in these CLs; the National Gender Policy and a concern raised in CLs with teacher educators: "who should translate policy into curriculum 'doable'?" For the deliberations, participants were divided into two focus groups that were purposefully divided into teacher educators as one group and DTE and $\mathrm{HO}$ as another. This was purposefully done to establish the boundaries and make them visible to all. Participants were given sufficient time to discuss and compile their points on flip charts. Board 5 summarizes the reports from the two groups:

Board 5 - Focus group summaries on: who should translate policy into curriculum "doable"

\begin{tabular}{|l|l|}
\hline Teacher Education Focus Group & $\begin{array}{l}\text { Department of Teacher Education and Head } \\
\text { Office Focus Group }\end{array}$ \\
\hline - Curriculum interpretation is usually for & - Curriculum interpretation is for lecturers \\
lecturers but when it comes to drawing & (teacher educators) and teachers; \\
from policy some external help may be & - For one to be a lecturer he or she should \\
required; & have skills and knowledge to put societal \\
- Some cross-cutting policy pronounce- & needs into the curriculum; \\
ments may not be accessible to professio- & - Colleges are semi-autonomous to design \\
nals; & curriculum for approval by DTE and HO; \\
- HO and UNESCO should assist in policy & - When the need arises, teacher educators can \\
interpretation in order to translate it into & seek for support from outside; \\
curriculum; & - Gender focal person can facilitate with staff \\
- DTE/HO should extend their supervisory & development funds permitting; \\
role to seeing to it that relevant policies are & - DTE play a supervisory role in curriculum \\
interpreted correctly. & review and student assessment. \\
\hline
\end{tabular}

Source: the authors.

The reports above demarcated the boundaries of operation. It became evident that the DTE and HO were inclined to maintain their supervisory role and leave policy interpretation and implementation to teacher educators. On the other hand teacher educators were at ease with their role but they felt at times that help may be needed to translate policy into curriculum practice. They echoed the same sentiments that they mentioned earlier in their change laboratory session, that some policy requirements are a bit divorced from their curriculum expertise and hence there is a need for help. Elements of boundary marking, demarcating and contesting became evident in these focus group reports. It appeared that teacher educators recognize the boundary but are willing to negotiate or contest it, as can be seen by: "yes we understand that we should translate policy into the curriculum practices, but some cross-cutting policy pronouncements are a bit divorced from our expertise so we need help." (verbal information). Akkerman and Bakker (2011) raised similar sentiments, noting that 
boundaries are discussed in a wide variety of social sciences to investigate how markers of difference are created, maintained, or contested at many different levels of institutionalization and categorization.

As discussions went on, it became apparent that both focus groups had neglected to address two of the unpacking questions: what does incorporating gender issues in the curricula mean and how can it be done? (from Board 2). The following session started with these questions. Again, work continued in the focus groups. The problem solving question for the DTE/HO focus group was: In your supervisory role (curriculum review and assessment) what would you expect to see that will inform you that gender issues are indeed incorporated into the curricula? For teacher educators the question was: What is your understanding of incorporating gender issues into the curriculum and what help may you need from eternal institutions like DTE/HO? These problem solving items were redesigned with the hope that they would guide participants to move between the past, the present and the future during analysis of problems and development of new solutions or tools for developing model solutions (ENGESTRÖM, 2016). Furthermore, the purpose of these was to deepen dialogicality. Markova (2003) described dialogicality in a boundary learning context as a Bakhtinian notion, the ontological characteristic of the human mind to conceive, create, and communicate about social realities through mutual engagement of the ego (i.e. self or selves) and others. Furthermore, problem solving items were designed to enhance the multi-voiced process of debate, negotiation and orchestration (ENGESTRÖM; SANNINO, 2010) in the expansive learning. Akkerman and Bakker (2011) added that Bakhtin's basic line of reasoning was that others or other meanings are required for any cultural category to generate meaning and reveal its depths. Board 6 provides a summary of the group reports:

Board 6 - Outcomes from the two focus groups

\begin{tabular}{|l|l|}
\hline Teacher Education Focus Group & DTE/HO Focus Group \\
\hline - First someone should tell us of the & - Syllabus and examination/assessment items \\
existence of a policy (we did not know & should reflect the issue (gender issues in this \\
about the National Gender Policy); & case); \\
- Incorporating into a curriculum goes & - We employ people who are competent, who \\
beyond talking about issues to engag- & should be able to engage with societal issues and \\
ing with specific issues. This may need & translate them into curriculum; \\
a real curriculum methodological re- & - We also have the ministry of gender that \\
orientation. & $\begin{array}{l}\text { should see to it that gender issues are incorpo- } \\
\text { rated into the curriculum. }\end{array}$ \\
\hline
\end{tabular}

Source: the authors. 
As deliberations continued in an open forum, teacher educators insisted "surely someone should inform us of the existence of the policy and it is reasonable for policy makers to come up with some implementing program." (verbal information). From this positioning and from the stance taken by DTE/HO, it appeared that there was a deadlock. To manage this, we had to get inspiration from Kerosuo and Engeström (2003, p. 348), who talk about the productivity of resistance; "resistance in learning is not an opposing force, but a process of exploring the unknown." To further explore the resistance that had emerged especially from the DTE/HO focus group, we thought of using identification as a mechanism of learning at the boundary. Identification entails a questioning of the core identity of each of the intersecting sites, questioning that leads to renewed insight into what the diverse practices concern (AKKERMAN; BAKKER, 2011). For this purpose we requested the DTE/HO to elaborate their role in curriculum development in general. The response from a senior Head Office member was "usually UNESCO gives the guidelines, the framework and to cascade this down when there is funding we run workshops otherwise the information is disseminated through the meetings with principals." (verbal information) This response, together with the one given earlier "we also have the Ministry of Gender that should see to it that gender issues are incorporated into the curriculum" (verbal information) were quickly captured by teacher educators who thought these statements are addressing their appeal for some help on policy implementation.

Deliberations shifted from questioning to suggesting how best to improve the flow of information between policy makers and implementers. As this happened, it became clear that the boundary mechanism had shifted from identification to coordination, a situation where individual actors analyze how effective means and procedures are sought allowing diverse practices to cooperate efficiently in distributed work, even in the absence of consensus (STAR, 2010). In the expansive learning cycle, this is tantamount to designing a model solution. Some of the suggestions that contributed towards a solution of improving the flow of information between policy makers and implementers are shown in Board 7.

These suggestions entail two processes of coordination; enhancing boundary permeability as well as routinization as boundary learning processes (AKKERMAN; BAKKER, 2011). Boundary permeability can be improved by reducing problematic discontinuities so that interactions run smoothly (AKKERMAN; BAKKER, 2011). As suggested above, absenting or reducing the impact of financial constraints as well as allowing more points of contact between institutions have the potential to enhance boundary permeability to the advantage of STEM teacher education curriculum development. 
Board 7 - Towards modelling solution

- No need for HO to seek huge amounts of funds, they can use institutional resources avai-
lable.
- HO can make use of workshops with Heads of Departments from colleges and these can
extend the same to their staff
- Principals' meetings not the best vehicle because of time, and perhaps the capacity of prin-
cipals to handle pedagogic issues in addition to administrative issues
- Gender focal person to work closely with teacher education and identify areas that are
more in need in terms of gender and dedicate time and resources towards those.
- Teacher educators should also be more resourceful and share expertise within them.

Source: the authors.

Closely related to boundary permeability is routinization, that is, "finding procedures by means of which coordination is becoming part of automatized or operational practice." (AKKERMAN; BAKKER, 2011, p. 13). Similarly within the suggestions this could be enhanced through multiple contact points and hence more exchanges than before between institutions through principals' meetings, Heads of Departments workshops and via the gender focal person. Engeström and Sannino (2010) and Engeström and Sannino (2010) called such emerging modes of collaboration in work settings that move toward co-configuration, "knotworking". In other words the suggestions in Board 7 were aimed at generating a new instrumentality for negotiated Knotworking.

As participants tried to come up with a model solution which they could work towards, we thought it was wise to deepen the discussion beyond the visible disturbances that advocate for obvious solutions, given inherent contradictions faced by the central activity system. It was clear that the learning that had taken place in these sessions could indeed assist in changing practice, a situation that could potentially result in curriculum transformation. Boundary Learning up to this point had been largely horizontal, placing emphasis on actions of bridging, negotiation and exchange across activity systems, or simply what Kerosuo and Engeström (2003) call collaboration of networks. Nevertheless, incorporating gender issues could require some vertical learning as well; this involves acquiring what Vygotsky (1978) would term scientific concepts. To deepen discussion accordingly we needed appropriate stimulating tool. In this regard, we decided to revisit the question of curriculum integration: "what does incorporating gender issues in the curricula mean and how can it be done?" We also decided to mirror various research findings that talk to the incorporation of gender issues in STEM. The information was contained in the handout referred above. This move was designed 
to give teacher educators a feel of the research evidence and indicates that there are many possible reasons that may contribute to girls' avoidance of science.

The idea was to support participants to develop a more holistic understanding of what it means to incorporate an issue into the curriculum, or as Engeström (2001, p. 68) said to "make disturbances and innovations visible and analyzable to practitioners and researchers." The stimulant was designed therefore to make participants realize that the modelled solution had to have more than mere increased boundary permeability.

As before, we had two focus groups to deliberate research findings and to try to answer the question. However the two groups were heterogeneous this time. Teacher educators were mixed with DTE and HO officials in each group, so that teacher educators could share the challenges that they face in implementing the policy pronouncements into the curriculum. Also, this would allow the opportunity for DTE and $\mathrm{HO}$ officials to make explicit their understanding of the object of curriculum transformation through policy implementation. The drive behind this was to encourage perspective making and perspective taking as reflexive processes in boundary learning. Boland Junior and Tenkasi (1995) referred to perspective making as making explicit one's understanding and knowledge of a particular issue, while perspective taking involves taking the other into account, in light of a reflexive knowledge of one's own perspective.

Reports showed that participants, especially the Head Office team, had the opportunity to look at themselves through the eyes of others. There was a significant shift in the perception of the object and the whole issue of gender incorporation into the curriculum. Teacher educators made their case clear that some of the curriculum transformation issues that were of a cultural and social nature, were a bit divorced from the Mathematics, the Physics, the IT and the Wood Technology etc. that they had learnt and hence they would require some help to transform the curriculum along those lines. In view of this, one senior member from HO summed it up by stating that:

usually funds are made available to bring in expertise for staff development of teacher educators for such curriculum transformations, but since the country got into economic challenges a few years ago, our donor community pulling out, we as Head Office, have found it difficult to come up with necessary staff development activities, and we have also learnt to keep quiet for political reasons, because we don't want people to keep on blaming the government,... I had to say this because we are really cornered here, but ordinarily we simply say competent lecturers should understand this and make things work. (verbal information). 
The utterance by a senior member brought to the fore causal mechanisms of the cultural history of practice that created current contradictions. As a group we went on to deliberate the implications of the statement. Perspective taking was quite visible among teacher educators who had up to this moment blamed DTE and HO staff for "reluctantly" supporting the gender agenda in teacher education curriculum. Everyone understood the social political climate in the country where government was intolerant of civil servants who may bring its name into disrepute by publicizing the shortfalls in its structures. Compassionate statements such as "it's understandable [...] now we understand, so amidst this how then can we move forward, what is the best way forward then" emerged with the idea of moving forward. Kerosuo and Engeström (2003, p. 348) called this a turning point, highlighting that such turning points "mark" the discovering of the joint object of the agents. As shown in this discussion the turning point was reached after a cluster of discursive disturbances (ENGESTRÖM; SANNINO, 2010) characterized by disagreements, conflicts and at times threats to continuity.

As deliberations continued, the focus turned more and more to how best we can move forward amidst the current circumstance of low funding, a rigid political climate and persistent gender inequality in STEM. Teacher educators came up with a proposal that they would want to strengthen the gender aspect of the syllabus in the ongoing syllabus review. It was explained that syllabi are reviewed every five years, and the cycle for the current review was at an advanced stage. It was also revealed that gender has always been a valid component in the education syllabus of each of the STEM but teacher educators had never treated it as a policy directive because they did not know about the existence of the National Gender Policy. In addition to that, none of the teacher educators had any experience of how to incorporate gender issues into the curriculum, nor could they engage with issues of socio-ecological risk and hence these issues were treated peripherally.

The gender focal person also added her weight to this: "we are in touch with a few organizations that can provide staff development for our teacher educators and probably produce teaching materials. When I get to the office, after this I am sure I can mobilize some resources and we can do the syllabus review together." (verbal information). These extracts show participants' commitment to new ways of doing work. Sannino (2008, p. 240) referred to this as "commissure speech acts". She further argued that such talk is agentive because it conveys that things are doable and shows an intention to act in specific ways.

There was consensus that there should also be a syllabus review committee comprising of mainly teacher educators, supported by the gender focal person and 
at least a representative from DTE and HO. The committee was quickly constituted. This confirmed that the change laboratories had resulted in participants moving from relatively insular or individualistic positions toward the position of a collective change agent through formation of new shared tools, rules and divisions of labor as observed by Virkkunen and Newnham (2013). This was a rather demanding process that brought together more than a single activity system. This was an example of hybridization that is when ingredients from different contexts are combined into something new and unfamiliar (VIRKKUNEN; NEWNHAM, 2003). It was acknowledged that it is the first time that representatives from the DTE and HO had committed to participate in the actual syllabus review process. In the past they had always played the role of directing or supervising from above.

\section{CONCLUSION}

This boundary learning phase could be described as transformative, that is moving towards modelling new ways of practice. Transformation as a boundary mechanism could be seen in two processes witnessed here: confrontation and recognizing a shared problem space (AKKERMAN; BAKKER, 2011). Confrontation as a necessary step for transformation entails encountering discontinuities that are not easily surpassed (AKKERMAN; BAKKER, 2011). Kerosuo and Engeström (2003) reasoned that confrontation with important boundaries can be caused by the appearance of a third perspective. In this case the appearance of the political climate into curriculum discussions added another dimension that had to be taken into account if transformation was to occur. There was also evidence of recognizing a shared problem space, in direct response to the confrontation. Teacher educators made empathetic suggestions as shown above. Key to boundary learning is the recognition of boundary objects as well.

This process of boundary learning makes us to reflect on Giroux's questioned "how can we make education meaningful by making it critical, and how do we make it critical so as to make it emancipatory." (SCOTT, 2008, p. 3). Considering that STEM curriculum development has been informed for centuries by patriarchal and instrumentalist ideas. Re-orienting curriculum in this case cannot be done superficially without shaking the instrumentalist and patriarchal roots that shape values of teacher educators. In this regard, Daniels (2012) reminded us that the way in which the social relations of institutions are regulated have cognitive and affective consequences for those who live and work inside them. Unterhalter and North (2011) support this, arguing that gender inequality is deeply imbued in the norms of institutions, 
their decision-making processes, forms of exercising power, their rules, unwritten cultures, and approaches to allocating resources. From an interventionist research point of view, we can conclude that the emergence and evolution of agency, more so transformative agency has been tightly connected to the motives and contradictions related to STEM curriculum. Our role in this regard has been to facilitate a process over a period of time that allowed actors to confront such contradictions and design better ways of doing work.

Our recommendation in this respect is that for successful curriculum re-orientation to occur, there is need to go beyond policy formulation. A systemic approach is required and a reflexive process to enable actors to engage with invisible or implicit mediational properties of institutional structures that shape human thought and action (DANIELS, 2012). As demonstrated in this paper, CHAT offers both conceptual and methodological tools that enrich mediation of such a process.

\section{REFERENCES}

AIKENHEAD, G. Whose scientific knowledge? The colonizer and the colonized. Counterpoints, v. 210, p. 151-166, 2002. Available from: <www.jstor.org/stable/42977984>. Access on: Jan. 032002.

AKKERMAN, S. F.; BAKKER, A. Boundary crossing and boundary objects. Review of Educational Research, v. 81, i. 2, p. 132-169, Jun. 2011.

AKKERMAN, S. F.; VAN EIJCK, M. Re-theorising the student dialogically across and between boundaries of multiple communities. British Educational Research Journal, v. 39, i. 1, p. 60-72, Feb. 2013.

BLACKER, F.; CRUMP, N.; MCDONALD, S. Organizing processes in complex activity networks. Organization Articles, v. 7, i. 2, p. 277-300, 2000.

BOLAND JUNIOR, R. J.; TENKASI, R. V. Perspective Making and Perspective Taking in Communities of Knowing. Organization Science, v. 6, i. 4, p. 350-372, Aug. 1995.

CLEGGY, A. Girls into science: a training module. Paris: Unesco, 2007.

CHIKUNDA, C. Assessing the level of gender awareness of science teachers: the case of Zimbabwe's two education districts. African Journal of Research in Mathematics, Science and Technology Education, v. 14, i. 3, p. 110-120, 2010. 
CHIKUNDA, C. Exploring and expanding capabilities, sustainability and gender justice in Science Teacher Education: case studies in Zimbabwe and South Africa. 2013. Thesis (Doctorate of Philosophy)-Rhodes University, Grahamstown, 2013.

CHIKUNDA, C. Identifying tensions around gender-responsive curriculum practices in science teacher education in Zimbabwe: an activity theory analysis. African Journal of Research in Mathematics, Science and Technology Education, v. 18, i. 3, p. 264-275, Sep. 2014.

CHIKUNDA, C. Surfacing contradictions around gender responsive curriculum practices in science teacher education in Zimbabwe. In: SELAU, B.; CASTRO, R. F. de (Ed.). Cultural-historical approach: educational research in different contexts. Porto Alegre: Ed. PUCRS, 2015. p. 61-72.

DANIELS, H. Institutional culture, social interaction and learning. Learning, Culture and Social Interaction, v. 1, i. 1, p. 2-11, 2012.

ENGESTRÖM, Y. Enriching the theory of expansive learning: Lessons from journeys toward coconfiguration. Mind, Culture, and Activity, v. 14, i. 1-2, p. 23-39, Dec. 2007.

ENGESTRÖM, Y. Expansive learning at work: Towards an activity theoretical re-conceptualization. Journal of Education and Work, v. 14, i. 1, p. 133-156, Aug. 2001.

ENGESTRÖM, Y.; MIETTINEN, R. Introduction. In: ENGESTRÖM, Y.; MIETTINEN, R.; PUNAMAKI, R. L. (Ed.). Perspectives on Activity Theory. New York: Cambridge University Press, 1999.

ENGESTRÖM, Y. New forms of learning in co-configuration work. In: WORK MANAGEMENT AND CULTURE SEMINAR, 2004, Califórnia. Annals... Califórnia, 2004.

ENGESTRÖM, Y.; SANNINO, A. Studies of expansive learning: Foundations, findings and future challenges. Educational Research Review, v. 5, i. 1, p. 1-24, 2010.

ENGESTRÖM, Y. Studies in expansive learning: learning what is not yet there. New York: Cambridge University Press, 2016.

FORUM FOR AFRICAN WOMEN EDUCATIONALISTS. Bringing genderresponsiveness to African education: advocacy, action and impact (FAWE Annual Report 2007). Nairobi: FAWE, 2008. 
KALU, I. Classroom interaction in physics lessons, relative to students' sex. African Journal of Research in Mathematics, Science and Technology, v. 9, i. 1, p. 55-66, Aug. 2005.

KEROSUO, H.; ENGESTRÖM, Y. Boundary crossing and learning in creation of new work practice. Journal of Workplace Learning, v. 15, i. 7-8, p. 345-351, 2003.

MARKOVA, I. Dialogicality and social representations: the dynamics of mind. Cambridge: Cambridge University Press, 2003.

MORNA, C. L.; NYAKUJARAH, L. J. (Ed.) SADC Gender Protocol Barometer. Johannesburg: Gender Links, 2011.

MUKUTE, M. Intergrating sustainability in school curriculum and practice: thae case of the schools and colleges permaculture programme in Zimbabwe. In: ICID+18, 2010, Fortaleza. Annals... Fortaleza, 2010.

PEAL, D.; WILSON, B. Activity theory and web-based training. In: KHAN, B. H. (Ed.). Web-based training. Englewood Cliffs, NJ: Educational Technology Publications, 2001. p. 147-153.

ROTH, W.; LEE, Y. Vygotsky's neglected legacy: cultural historical activity theory. Review of Educational Research, v. 77, i. 2, p. 86-232, Jun. 2007.

SANNINO, A. From talk to action: Experiencing interlocution in developmental interventions. Mind, Culture, and Activity, v. 15, i. 3, p. 234-257, 2008.

SCOTT, D. Critical essays on major curriculum theorists. London: Routledge, 2008.

SELAU, B.; CASTRO, R. F. de. (Org.). Cultural-historical approach: educational research in different contexts. Porto Alegre: Ed. PUCRS, 2015.

SHOTTER, J; KATZ, A. M. 'Living moments' in dialogical exchanges. Human Systems: The Journal of Systemic Consultation and Management, v. 9, i. 2, p. 81-93, 1999.

SINNES, A. T. Approaches to gender equity in science education: Three alternatives and two examples. African Journal of Research in Mathematics, Science and Technology Education, v. 10, i. 1, p. 1-12, 2006.

STAR, S. L. This is not a boundary object: Reflections on the origins of the concept. Science, Technology and Human Values, v. 35, i. 5, p. 601-617, Aug. 2010. 
UNTERHALTER, E.; NORTH, A. Responding to the gender and education. Millennium Development in South Africa and Kenya: Reflections on education rights, gender equality, capabilities and global justice. Compare: A Journal of Comparative and International Education, v. 41, i. 4, p. 495-511, Jun. 2011.

VASILYUK, F. E. The psychology of experiencing: an analysis of how critical situations are dealt with. Moscow: Progress, 1988.

VIRKKUNEN, J.; NEWNHAM, D. S. The Change Laboratory A Tool for Collaborative Development of Work and Education. Taipei: Sense Publishers, 2013.

VYGOTSKY, L. Mind in society: the development of higher psychological processes. Cambridge: Havard University Press, 1978.

WARMINGTON, P. et. al. Learning in and for interagency working: TLRP Annual Progress Report. Bath: University of Bath, 2005.

ZIMBABWE. Millennium Development Goals Status Report. Republic of Zimbabwe, 2010.

Recebido em: 19 de julho de 2017 Aceito em: 10 de outubro de 2017

Endereço para correspondência: Rua Padre Ângelo Cerri, 2132, Bairro São João Bosco, 76803-780, Porto Velho, Rondônia, Brasil; castro@unir.br 